\title{
HUBUNGAN ANTARA KECEMASAN BELAJAR MATEMATIKA DENGAN DISPOSISI MATEMATIS SISWA DI SMP NEGERI 2 LUWUK
}

\author{
Edy Wibowo \\ Universitas Tompotika Luwuk Jl. Dewi Sartika No 65 Telp/Fax 046121411 \\ Program Studi Pendidikan Matematika, Fakultas Keguruan dan Ilmu Pendidikan, \\ Universitas Tompotika Luwuk, Kab. Banggai \\ e-mail: wibowo.fkip@gmail.com
}

\begin{abstract}
Abstrak. Penelitian ini bertujuan untuk mengetahui hubungan antara kecemasan belajar matematika siswa dengan disposisi matematis siswa kelas VIII SMP N 2 Luwuk. Metode penelitian yang digunakan adalah metode survei dengan pendekatan korelasional. Populasi penelitian ini adalah seluruh siswa SMP Negeri 2 Luwuk kelas VIII Tahun Pelajaran 2016/2017 sebanyak 304 orang yang tersebar pada 8 kelas. Pengambilan sampel dilakukan secara proportionate random sampling sebanyak 15\% dari banyaknya populasi sehingga diperoleh sampel sebanyak 46 orang. Instrumen yang digunakan dalam penelitian ini berupa angket. Analisis data penelitian ini dilakukan secara analisis deskriptif dan analisis inferensial. Analisis yang digunakan untuk menguji hipotesis adalah regresi sederhana dan analisis korelasi. Hasil dari regresi sederhana diperoleh model regresi adalah $\hat{Y}=1359.1-0,43 \mathrm{X}$ dengan $F_{\text {hitung }}=26.6>F_{\text {tabel }}=4.06$ artinya sangat signifikan. Hasil penelitian menunjukan bahwa terdapat hubungan negatif dan signifikan. Dengan koefisien korelasi $(r)=-0,612$ yaitu signifikan, dan $t_{\text {hit }}=10,457$ sedangkan $t_{\text {tabel }}=1,645$ maka diperoleh $t_{\text {hit }}=10,457>t_{\text {tabel }}=1,645$ yang menyatakan bahwa terdapat hubungan negatif antara kecemasan belajar matematika siswa dengan disposisi matematis, yaitu semakin tinggi tingkat kecemasan belajar matematika Siswa, akan semakin rendah disposisi matematis.
\end{abstract}

Kata kunci: Kecemasan, Matematika, Disposisi

\begin{abstract}
This research aims to determine the correlation between mathematics anxiety and mathematis disposition Of students in VIII grade of SMP N 2 Luwuk. The Methodology of the research is survey with correlational approach. Population of this research are all of students in VIII grade of SMP N 2 Luwuk of 2016/2017 academic year, which us consist of 304 students in eight classes. Sampling is done by implementing proportionate random sampling in $15 \%$ from total population. So ,there is 46 students as research sample. The instrument used in this study is a questionnaire. Data analysis of this research are descriptive analysis used in examine the hypotheses are correlation analysis and simple regression. The result of simple regression obtained by regression model is 1359.1-0,43x with F_hitung $=26,6>$ F_table $=4,06$ means very sign. The Results showed that negative and significant relationship. Correlation coefisien $(r)=-0.612$ is siginificant, and $t_{\text {count }}=$ 10,457 , while $t_{\text {table }}=1,645$. so $t_{\text {count }}=10,457>t_{\text {table }}=1,645$ it showed that there were a negative correlation between mathematics anxiety and mathematical disposition, which is the higher level of mathematics anxiety, so lower the mathematical disposition.
\end{abstract}

Keywords: Anxiety,Mathematical, Disposition.

\section{Pendahuluan}

Matematika merupakan salah satu pelajaran yang dipelajari mulai dari sekolah dasar hingga perguruan tinggi. Spencer dan Brydegaar dalam (Asriadi, 2010) menyatakan matematika sebagai ilmu bahasa seni karena bentuk-bentuk khusus yang ditemukan dapat mengekspresikan dan mengkomunikasikan pesan-pesan secara matematika. Matematika sebagai sains, karena matematika dihasilkan oleh penemuan dan percobaan dan isinya terorganisir secara sistematis. Matematika sebagai 
ilmu seni estetika karena matematika bersangkut paut dengan bentuk-bentuk simetris. Dan matematika sebagai ilmu rekreasi karena menemukan kesenangan dan relaks dalam mempelajari isinya. Sebagai salah satu mata pelajaran di sekolah dan juga menjadi salah satu mata pelajaran yang menentukan kelulusan disetiap jenjang pendidikan,matematika menjadi mata pelajaran yang sangat penting untuk diajarkan. Namun sering kali kita mendapatkan anggapan sampai sekarang masih ada beberapa siswa mengatakan pelajaran matematika adalah pelajaran yang sulit, menakutkan sehingga siswa kurang berminat mempelajari matematika, sebagaimana hasil penelitian oleh (Pamuji \& Yuzianah, 2014) menyatakan bahwa matematika matematika merupakan pelajaran yang sulit dan membosankan.

Anggapan maupun pandangan matematika sebagai pelajaran yang sulit dapat menimbulkan sikap yang berbeda bagi masing-masisng siswa. Hal tersebut didapatkan ketika peneliti melakukan observasi serta wawancara guru matematika di SMP Negeri 2 Luwuk ketika siswa mendengar kata matematika muncul respon negatif dari siswa diantaranya ada yang beranggapan matematika sangat menguras otak, menyeramkan, ketika belajar merasa takut ketika guru mempersilahkan maju di depan kelas untuk menjawab soal namun ada yang juga menyukai matematika karena gemar berhitung dan memecahkan masalah.

Dari pandangan tentang matematika di atas tentunya menghasilkan sikap suka atau tidak suka terhadap matematika.Sikap tersebut bisa positif bila siswa menanggapi sebagai suatu tantangan dan tidak akan merasa puas bila ada soal yang belum ditemukan pemecahannya sehingga siswa terpacu untuk terus belajar. Namun juga bisa negatif yang ditampakan oleh siswa seperti malas untuk belajar matematika dan merasa tertekan bila mempelajari pelajaran matematika bahkan kalau kita mengamati ketika standar kelulusan ditentukan oleh sekolah yang tentunya menghadirkan berbagai macam kebijaksanaan untuk bisa meluluskan siswanya maka mempelajari matematika dianggap oleh siswa sebagai sesuatu yang formalitas.

Dalam mempersiapkan pembelajaran matematika maupun pada proses pembelajarannya seorang guru harus memperhatikan aspek siswa berkaitan dengan perasaan siswa tentang matematika itu sendiri dalam hal ini Math Anxiety (Kecemasan Belajar Matematika)," Thus, children as early as first and second grade reported feeling "nervous" for various math-related situations,'(Ramirez, Gunderson, Levine, \& Beilock, 2013). Siswa Merasa "gugup" dalam berbagai situasi yang berhubungan dengan matematika. Math Anxiety ini memberikan dampak pada kesiapan mental siswadalam belajar matematika. Mathematics anxiety, considered a fear or phobia, produces 'a negative response specific to the learning, or doing, of mathematical activities that interferes with performance'(Whyte \& Anthony, 2012). Pendapat Whyte dan Antoni menegaskan bahwa kecemasan matematika merupakan respon negatif terhadap segala aktifitas yang berkaitan dengan matematika (Pembelajaran Matematika).

Penulis berpandangan bahwa seandainya siswa memiliki tingkat kecemasan yang normal pada saat belajar matematika, maka sikap terhadap matematika menghasilkan sikap yang positif. Namun, apabila tingkat kecemasan siswa sudah melebihi tingkat kenormalan, maka sikap terhadap matematika yang diperoleh malah akan lebih buruk rendah. Hal ini senada dengan pendapat Ramaiah dalam (Asriadi, 2010) bahwa, kecemasan yang tinggi bisa berpengaruh buruk pada pekerjaan seseorang, apalagi jika timbulnya sering kali. Sikap atau cara pandang terhadap sesuatu yang direspon dengan negatif maka menghasilkan cara pandang yang negatif pula begitupun sebaliknya,dengan demikian cara pandang siswa terhadap matematika akan menghasilkan apa yang disebut dengan Disposisi Matematis.

Sumarno dalam (Suharsono, 2015)Mendefinisikan disposisi matematis sebagai keinginan, kesadaran dan dedikasi yang kuat pada diri siswa untuk berpikir dan berbuat secara matematik. Selanjutnya pendapat Katz dalam (Mahmuzah \& Ikhsan, 2014) yang mengatakan bahwa disposisi matematis berkaitan dengan bagaimana siswa menyelesaikan masalah matematis, apakah mereka menyelesaikannya dengan penuh rasa percaya diri, tekun, berminat, dan berpikir fleksibel untuk 
menemukan berbagai alternatif penyelesaian masalah. Berdasarkan hasil penelitian (Nurbaiti Widyasari, Jarnawi A Dahlan, 2016) siswa kelas VIII sudah diasumsikan cukup dewasa dalam belajar, tetapi dalam kenyataannya siswa kelas VIII masih perlu diberikan dorongan dari luar khususnya guru agar memiliki sikap yang positif terhadap apa yang mereka pelajari. Oleh karena itu diperlukan informasi terkait sikap siswa terhadap matematika atau disposisi Matematis dengan kecemasan yang terjadi pada siswa pada saat belajar matematika. Penelitian ini bertujuan untuk mengetahui keterkaiatan antara disposisi matematis dengan kecemasan belajar matematika.

\section{Metode Penelitian}

Metode yang digunakan dalam penelitian ini adalah metode survei dengan pendekatan korelasional dan dengan variabel bebas (X) adalah kecemasan belajar matematika dan variabel terikat (Y) adalah Disposisi Matematis Populasi dalam penelitian ini adalah seluruh siswa kelas VIII SMP Negeri 2 Luwuk tahun pelajaran 2016-2017 dengan jumlah siswa 304 orang yang tersebar pada 8 kelas dan teknik pengambilan sampel yang digunakan dalam penelitian ini adalah proportionate random sampling, sampel dalam penelitian ini ditetapkan sebesar $15 \%$ dari jumlah populasi. Dalam rangka penetapan sampel (Arikunto, 2002) mengemukakan bahwa apabila populasi lebih dari 100 orang maka sampel yang diambil adalah sebanyak $10 \mathrm{~s} / \mathrm{d} 15 \%$ atau $20 \mathrm{~s} / \mathrm{d}$ 25\%. Sedangkan apabila populasinya kurang dari 100 orang maka sampelnya adalah seluruh populasi. Berdasarkan pendapat tersebut, sampel dalam penelitian ini ditetapkan sebesar $15 \%$ dari jumlah populasi. Banyaknya sampel yang dipilih dapat dilihat pada perhitungan berikut.

$$
\begin{aligned}
& \text { Sampel }=\text { Populasi } \times 15 \% \\
& \text { Sampel }=304 \times \frac{15}{100} \\
& \text { Sampel }=45,6 \approx \text { dibulatkan menjadi } 46 \text { orang. }
\end{aligned}
$$

Penetapan sampel untuk kelas VIII-1 dapat dilihat pada perhitungan berikut.

$$
\begin{aligned}
& \text { Kelas VII-1 jumlah populasi }=39 \text { orang } \\
& \text { Sampel }=39 \times 15 \% \\
& \text { Sampel }=39 \times \frac{15}{100} \\
& \text { Sampel }=5.8 \approx \text { dibulatkan menjadi } 6 \text { orang. }
\end{aligned}
$$

Dengan cara yang sama seperti perhitungan di atas, penentuan sampel untuk masingmasing kelas dapat dilihat pada Tabel 1 
Tabel 1. Data Penyebaran Anggota Sampel Siswa Kelas VIII SMP Neg. 2 Luwuk Tahun Pelajaran 2016-2017.

\begin{tabular}{cccc}
\hline No. & Kelas & Populasi & Sampel \\
\hline 1. & VIII $^{\mathrm{a}} 1$ & 39 & 6 \\
2. & VIII $^{\mathrm{a}} 2$ & 38 & 6 \\
3. & VIII $^{\mathrm{a}} 3$ & 37 & 6 \\
4. & VIII $^{\mathrm{a}} 4$ & 38 & 6 \\
5. & VIII $^{\mathrm{a}} 5$ & 37 & 6 \\
6. & VIII $^{\mathrm{a}} 6$ & 38 & 6 \\
7. & VIII $^{\mathrm{a}}$ 7 & 39 & 6 \\
8. & VIII $^{\mathrm{a}} 8$ & 38 & 6 \\
\hline & Jumlah & 304 orang & 46 orang \\
\hline
\end{tabular}

Jenis validitas dalam penelitian ini adalah validitas empirik. Analisis validitas empirik menggunakan Korelasi Product Moment (Keysar, 2010) dan reliabilitas instrumen penelitian menggunakan Alpha Crombach (Sugiyono, 2015). Instrumen Kecemasan belajar matematika dan disposisi matematis diuji cobakan kepada 30 responden di luar sampel penelitian, dari 40 butir pertanyaan angket kecemasan belajar yang dinyatakan valid berjumlah 33 butir sedangkan 7 butir dinyatakan gugur dengan reliabilitasnya 0,9453 diartikan sangat tinggi sedangkan angket disposisi matematis dari 30 butir pertanyaan yang dinyatakan valid sebanyak 28 butir dan 2 butir pertanyaan dinyatakan gugur dengan reliabilitasnya 0,907 diartikan sangat tinggi, serta teknik analisis data yang digunakan dalam penelitian ini terdiri atas dua bagian, yaitu analisis deskriptif dan analisis inferensial. Analisis deskriptif dilakukan untuk menyajikan data setiap variabel dalam besaran-besaran statistik seperti rata-rata (mean), nilai tengah (median), frekuensi terbanyak (modus), simpangan baku (standar deviasi), dan menvisualisasikannya ke dalam bentuk tabel distribusi frekuensi dan histogram, sedangkan analisis inferensial digunakan untuk menguji hipotesis penelitian. Sebelum menguji hipotesis harus memenuhi uji prasyaratnya yakni Uji Normalitas Data dengan menggunakan Uji Normalitas Galat Taksiran dan Uji Linearitas menggunakan Uji Fisher (Abbas, 2012) .

\section{Hasil Penelitian dan Pembahasan}

Hasil pengujian analisis deskriptif data penelitian data yang dideskripsikan dalam penelitian ini terdiri dari: disposisi matematis peserta didik (Y) dan kecemasan belajar $(\mathrm{X})$. skor masing-masing data ini dideskripsikan dalam bentuk rata-rata atau mean (M), median (Me), modus (Mo), dan standar deviasi (SD). Rekapitulasi data hasil penelitian disajikan pada tabel 2.

Tabel 2. Rekapitulasi skor Data Hasil Penelitian

\begin{tabular}{cccccccc}
\hline \multirow{2}{*}{ Variabel } & \multicolumn{7}{c}{ Data } \\
\cline { 2 - 8 } & $\begin{array}{c}\text { Skor Min } \\
28\end{array}$ & $\begin{array}{c}\text { Skor Max } \\
112\end{array}$ & Range & Mean & Median & Modus & SD \\
\hline Y & 40 & 105 & 65 & 73,21 & 78,28 & 77,28 & 14,6 \\
X & 36 & 128 & 92 & 92,5 & 97,8 & 83,3 & 21,8 \\
\hline
\end{tabular}

Keterangan:

$\mathrm{Y}=$ Disposisi Matematis Peserta Didik . 


\section{$\mathrm{X}=$ Kecemasan Belajar Peserta Didik}

Pengujian persyaratan analisis data yang dimaksudkan dalam penelitian ini adalah pengujian normalitas galat regresi, disposisi matematis (Y) atas Kecemasan Belajar Matematika (X). Pengujian normalitas data menggunakan uji galat taksiran (Y- $\hat{Y})$ dengan menggunakan uji Lilliefors $\left(l_{0}\right)$ Hipotesis statistik yang diuji dinyatakan sebagai berikut:

$\mathrm{H}_{0} \quad$ : Populasi galat taksiran berdistribusi normal

$\mathrm{H}_{1} \quad$ : Populasi galat taksiran tidak berdistribusi normal

Kriteria pengujiannya adalah $\mathrm{H}_{0}$ jika $L_{0} \leq L_{\text {tabel }}$ dan tolak $\mathrm{H}_{0}$ jika $L_{0}>L_{\text {tabel }}$ pada taraf nyata $\alpha$ yang dipilih. Dalam penelitian ini dipilih $\alpha=0,05$, sehingga untuk $\mathrm{n}=46$ maka nilai $L_{\text {tabel }}=\frac{0,886}{\sqrt{46}}=0,1306$.

Dari hasil perhitungan dengan menggunakan bantuan program Excel For Windows 2007 diperoleh $L_{0}=0,09807$. Karena nilai $L_{0}=0,09807<L_{\text {tabel }}=0,1306$ maka di simpulkan bahwa galat regresi Y atas X berdistribusi normal. Dalam hal ini data berasal dari populasi berdistribusi normal, yang berarti persyaratan normalitas data untuk regresi linear sederhana $\mathrm{Y}$ atas $\mathrm{X}$ dipenuhi.

Tabel 3. Rangkuman hasil uji normalitas galat regresi

\begin{tabular}{cccc}
\hline \multirow{2}{*}{ Galat taksiran } & $L_{0}$ & $L_{t}$ & \multirow{2}{*}{ Kesimpulan } \\
\cline { 3 - 3 } & & $\alpha=0,05$ & \\
\hline$(\mathrm{Y}-\hat{Y})$ & 0,09807 & 0,1306 & Normal \\
\hline
\end{tabular}

Untuk mengetahui kelinearan dan derajat signifikansi (keberartian regresi) digunakan uji F. Dengan menggunakan bantuan program program Excel For Windows 2007 diperoleh nilai F seperti tampak pada Tabel 3.

Tabel 4. Rangkuman ANAVA untuk uji signifikansi dan linearitas

\begin{tabular}{cccccc}
\hline Sumber varians & Dk & JK & RJK & $\mathbf{F}_{\text {hitung }}$ & $\mathbf{F}_{\text {tabel }}$ \\
\hline Total & 46 & 250152 & - & - & \\
\hline Regresi (a) & 1 & 245718,34 & & & \\
Regresi (b|a) & 1 & 4106,3 & 6154,7448 & $26,6^{* * *}$ & 4,06 \\
Sisa & 44 & 6799,36 & - & & \\
\hline Tuna cocok & 32 & 8550,81 & 267,2 & \multirow{2}{*}{$1,83^{\text {ns }}$} & 2,4 \\
Galat & 12 & 1751,45 & 145,9 & & \\
\hline
\end{tabular}

\begin{tabular}{ll}
\multicolumn{2}{l}{ Keterangan: } \\
dk & : Derajat kebebasan \\
JK & : Jumlah Kuadrat \\
RJK & : Rata-rata Jumlah Kuadrat \\
ns & : Regresi Berbentuk linear \\
$* *$ & : Sangat signifikan
\end{tabular}


Dari tabel ANAVA di atas diperoleh $F_{\text {hitung }}=1,83$ untuk taraf nyata $\alpha=0,05 \mathrm{dk}$ pembilang $=32$ dan $\mathrm{dk}$ penyebut $=12$ diperoleh $F_{(0,95)(53,11)}=2,46$. Dengan kriteria pengujian Jika $F_{\text {hitung }} \leq F_{\text {tabel }}$ maka model regresi berbentuk linear, dalam hal lain jika $F_{\text {hitung }}>F_{\text {tabel }}$, maka model regresi tidak berbentuk linear pada taraf signifikansi $\alpha=0,05$ dengan derajat kebebasan $(\mathrm{dk})$ pembilang $=\mathrm{k}-2$ dan dk penyebut $=\mathrm{n}-\mathrm{k}$. Karena $F_{\text {hitung }}=$ $1,83<F_{\text {tabel }}=2,46$, berarti persamaan regresi $\hat{Y}=1359,1-0,43 \mathrm{X}$ berbentuk linear. Persamaan regresi ini mengandung arti bahwa setiap kenaikan satu unit skor kecemasan belajar, akan diikuti oleh penurunan skor disposisi matematis peserta didik sebesar 0,43 unit pada konstanta 1359,1.

Tabel 5. Rangkuman Hasil Perhitungan Uji Signifikansi Koefisien Korelasi

\begin{tabular}{|c|c|c|c|c|c|c|}
\hline $\mathrm{N}$ & Dk & $r_{x y}$ & $r^{2}$ & Kontribusi (\%) & $t_{\text {hit }}$ & $\frac{t_{\text {tabel }}}{\alpha=0,05}$ \\
\hline 46 & 44 & $-0,612$ & 0,3745 & 37,45 & $10,457 * *$ & 1,645 \\
\hline \multicolumn{7}{|c|}{ Keterangan: } \\
\hline \multicolumn{7}{|c|}{$\mathrm{n} \quad=$ Jumlah Responden } \\
\hline \multicolumn{7}{|c|}{$\begin{aligned} r_{x y} & =\text { Koefisien Korelasi antara Kecemasan Belajar Peserta Didik dengan Disposisi matematis } \\
& \text { matematika }\end{aligned}$} \\
\hline$r^{2}=$ & \multicolumn{6}{|c|}{$\begin{array}{l}=\text { Koefisien Determinasi antara Kecemasan Belajar Peserta Didik dengan Disposisi matematis } \\
\text { Matematika }\end{array}$} \\
\hline \multicolumn{7}{|c|}{ עo } \\
\hline
\end{tabular}

Nilai koefisien korelasi antara kecemasan belajar Peserta Didik dengan Disposisi matematis $\left(r_{x y}\right)$ sebesar -0,612. Nilai ini mengindikasikan bahwa hubungan antara kecemasan belajar peserta didik dengan disposisi matematis matematika adalah hubungan negatif dan kuat. Kuatnya hubungan kecemasan belajar dengan disposisi matematis matematika, ditunjukkan pula oleh harga koefisien determinasi $\left(r^{2}\right)$ sebesar 0,3745 dengan kontribusi $37,45 \%$. Artinya ada sebesar $37,45 \%$ variasi Disposisi matematis dapat dijelaskan oleh kecemasan belajar, sedangkan $62,55 \%$ ditentukan oleh faktor lain, misalnya faktor eksternal seperti sarana dan prasarana belajar, lingkungan keluarga, serta keterampilan dan keahlian guru dalam mengajar. Dengan kata lain, Disposisi matematis peserta didik ditentukan pula oleh kecemasan belajar. Kecemasan belajar sangat menentukan sikap peserta didik terhadap matematika (disposisi matematis) bahkan juga terhadap prestasi belajar siswa, oleh karena itu peran guru sangat diutamakan untuk menciptakan suasana pembelajaran yang meminimalisir kecemasan belajar matematika, hal ini sejalan dengan kesimpulan dari (Saputra, 2014) bahwa dalam mengurangi kecemasan belajar matematika terletak pada kemampuan seorang guru guru dalam memahami siswa dan terus mencoba dalam membawa pelajaran matematika kearah yang lebih baik dan mudah diterimah dan disenangi oleh siswa.

\section{Kesimpulan}

1. Berdasarkan kesimpulan hasil pengujian hipotesis penelitian, dapat dikatakan bahwa terdapat hubungan negatif antara kecemasan belajar dengan Disposisi matematis matematika.

2. Kecemasan matematika merupakan respon negatif terhadap segala aktifitas yang berkaitan dengan Matematika (Pembelajaran Matematika). 
3. Disposisi matematis sebagai keinginan, kesadaran dan dedikasi yang kuat pada diri siswa untuk berpikir dan berbuat secara matematik.

4. Untuk disposisi matematis siswa SMP Negeri 2 Luwuk tinggi atau rendah sangat bergantung dari kecemasan yang dimiliki oleh siswa dalam pembelajaran matematika.

5. Kecemasan tinggi pada siswa berakibat pada depresi dan ketakutan terhadap matematika serta memberikan dampak pada rendahnya disposisi matematis siswa.

\section{Saran}

1. Perlu Penelitian lanjutan dengan metode Kualitatif Deskriptif untuk menganalisis masing-masing kecemasan belajar matematika dan disposisi matematis siswa

2. Guru hendaknya selalu membuat lingkungan belajar yang kondusif dan melaksanakan pembelajaran yang menarik perhatian khususnya pembelajaran matematika dan selalu memberikan motivasi kepada siswa agar kecemasan yang ada pada siswa bisa diminimalisasi atau bahkan dapat dihindarkan pada saat siswa menghadapi, melalui matapelajaran matematika.

\section{Daftar Pustaka}

Abbas, N. (2012). Bahan Ajar Statistika Penelitian (1st ed.). Gorontalo: Pascasarjana Universitas Negeri Gorontalo.

Arikunto, S. (2002). Prosedur Penelitian Suatu pendekatan Praktek. Jakarta: Rineka Cipta.

Asriadi. (2010). Hubungan antara Kecemasan Belajar Siswa dengan Hasil Belajar Matematika. Gorontalo: FMIPA UNG.

Keysar, P. (2010). Merancang Butir Soal dan Instrumen untuk Penelitian (Pertama). Gorontalo: BMT Nurul Jannah.

Mahmuzah, R., \& Ikhsan, M. (2014). Peningkatan Kemampuan Berpikir Kritis dan Disposisi Matematis Siswa SMP dengan Menggunakan Pendekatan Problem Posing. Jurnal Didaktik Matematika, 1(2), 43-53.

Nurbaiti Widyasari, Jarnawi A Dahlan, S. D. (2016). MENINGKATKAN KEMAMPUAN DISPOSISI MATEMATIS SISWA SMP MELALUI PENDEKATAN METAPHORICAL THINKING. FIBONACCI Jurnal Pendidikan Matematika \& Matematika, 2(2), 28-39.

Pamuji, T., \& Yuzianah, D. (2014). PERSEPSI TERHADAP MATA PELAJARAN MATEMATIKA SISWA SMP KELAS VIII. Ekuivalen Jurnal Pendidikan Matematika, 12(4), 293-298.

Ramirez, G., Gunderson, E. A., Levine, S. C., \& Beilock, S. L. (2013). Math Anxiety, Working Memory, and Math Achievement in Early Elementary School. Journal of Cognition and Development. https://doi.org/10.1080/15248372.2012.664593

Saputra, P. R. (2014). Kecemasan Matematika Dan Cara Menguranginya ( Mathematic 
Anxiety and How To Reduce It ). Pyhthagoras Jurnal Pendidikan Matematika Unrika, 3(2), 75-84.

Sugiyono. (2015). Statistika Untuk Penelitian (26th ed.). Bandung: Alfabeta.

Suharsono. (2015). MENINGKATKAN KEMAMPUAN PEMAHAMAN DAN DISPOSISI MATEMATIK SISWA SMA MENGGUNAKAN TEKNIK PROBING PROMPTING. Edusentris, Jurnal Ilmu Pendidikan Dan Pengajaran, 2(3), 278-289.

Whyte, J., \& Anthony, G. (2012). Maths Anxiety: The Fear Factor in the Mathematics Classroom. New Zealand Journal of Teachers' ..., 9(1), 6-15. Retrieved from http://www.teacherswork.ac.nz/journal/volume9_issue1/whyte.pdf 